\title{
KONSEP PENGUATAN KEWENANGAN KOMISI PENGAWAS PERSAINGAN USAHA SEBAGAI LEMBAGA QUASI-PERADILAN DALAM MEMBANGUN PEREKONOMIAN NASIONAL YANG SEHAT DAN ADIL
}

\author{
THE CONCEPT OF STRENGTHENING THE AUTHORITY \\ OF THE COMMISSION FOR SUPERVISING BUSINESS \\ COMPETITION AS A QUASI-JUSTICE INSTITUTION IN \\ BUILDING A HEALTHY AND ADI NATIONAL ECONOMY
}

\author{
Muh. Risnain \\ Dosen Fakultas Hukum Universitas Mataram NTB \\ Email : risnain82@gmail.com
}

Naskah diterima : 10/07/2018; direvisi : 27/07/2018; disetujui : 27/07/2018

\begin{abstract}
The purpose of this study is to state that KPPU as a quasi-judicial institution has an important role in economic development, then it will compare between KPPU and other institutions that have competition supervisory institutions, and KPPU in the competition dimension in Indonesia. this research method is a type of juridicalnormative research. This study aims to design and mitigate KPPU as the supervisor and concept of KPPU as a quasi-judicial institution in achieving a healthy and fair national economy. . Conducting research with supervisory and law enforcement agencies in other countries such as the United States, Germany and Japan is carried out by the Indonesian Parliament and the President in order to realize the Authority of the Commission.
\end{abstract}

\section{Keyword : Authority, supervisory, business competition, quasi judicial}

\begin{abstract}
Abstrak
Tujuan penelitian ini adalah untuk mengungkapkan keberadaan KPPU sebagai lembaga quasi-yudisial yang memiliki peranan penting dalam membangun perekonomian nasional, kemuidan akan membandingkan keberadaan KPPU dengan lembaga serupa yang dimiliki negara lain yang telah terlebih dahulu memiliki lembaga pengawas persaingan usaha, dan menemukan sebuah konsep penguatan kewenangan KPPU dalam mengawasi persaingan usaha di Indonesia. metode penelitian ini adalah jenis penelitian yuridis-normatif. Penelitian ini mendiskripsikan dan menganalisis kebijakan hukum yang diambil pemerintah terkait kelembagaan KPPU sebagai pengawas persaingan usaha dan berusaha menemukan konsep penguatan KPPU sebagai lembaga quasi yudisial dalam mewujdukan perekonomian nasional yang sehat dan adil. . Melakukan kajian perbandingan dengan lembaga pengawas dan penegak hukum persaingan usaha di negara lain seperti di Amerika Serikat, Jerman dan Jepang hendaknya dilakukan DPR RI dan Presiden dalam rangka memperkuat Kewenangan KPPU.
\end{abstract}

Kata kunci : Kewenangan, Pengawas, Persaingan Usaha, Quasi Peradilan 


\section{PENDAHULUAN}

Kelahiran Undang-Undang Nomor 5 Tahun 1999 tentang Larangan Praktik Monopoli dan Persaingan Usaha Tidak Sehat (Undang-Undang Anti Monopoli) pada awal-awal reformasi adalah langkah pertama bangsa Indonesia untuk melakukan penataan perekonomian nasional menuju perekonomian nasional yang sehat dan adil. Tujuannya adalah untuk menjaga kepentingan umum dan melindungi konsumen, menumbuhkan iklim usaha yang kondusif melalui terciptanya persaingan usaha yang sehat dan menjamin kepastian kesempatan berusaha yang sama bagi setiap orang, mencegah praktek-praktek monopoli serta menciptakan efektivitas dan efisiensi dalam rangka meningkatkan pertumbuhan ekonomi nasional.

Adalah sebuah kenyataan bahwa perekonomian yang diciptakan pada masa sebelum lahirnya undang-undang anti monopoli, perekonomian nasional diwarnai ekonomi monopolistik karena adanya kolusi antara penguasa dengan pengusaha maupun antara sesama pengusaha. Perekonomian nasional hanya dikuasai oleh segelintir orang yang ada pada lingkaran kekuasaan. Ekonomi kekeluargaan sebagai prinsip ekonomi nasional disalahgunakan menjadi perekonomian hanya dikuasai oleh keluarga dan kelompok tertentu. Undangundang anti monopoli hadir untuk memperbaiki perekonomian nasional yang carut marut dan penuh dengan ketidakadilan.

Diundangkannya Undang-Undang Nomor 5 Tahun 1999 tidak saja membawa angin baru bagi regulasi persaingan usaha di Indonesia yang selama ini tersebar dalam berbagai peraturan perundang-undangan, namun juga melahirkan lembaga baru yaitu Komisi Pengawas Persaingan Usaha
(KPPU) ${ }^{1}$. Pasal 30 Undang-Undang Nomor 5 tahun 1999 menetapkan KPPU sebagai lembaga pengawas pelaksanaan undang-undang tersebut. Fungsi pengawasan yang diemban KPPU kemudian didukung dengan tugas dan kewenangan KPPU sebagaimana diatur Pasal 35 dan Pasal 36 Undang-Undang Anti monopoli. Untuk mewujudkan masyarakat madani (civil society) yang kuat dalam rangka mewujudkan masyarakat yang adil dan makmur yang merata, baik materiil maupun spiritual sehingga perlu adanya intervensi Negara dalam mengatur mekanisme pasar. Karena dengan mekanisme pasar yang sehat kegiatan prekonomian dalam masyarakat prekonomian dalam masyarakat bisa menghasilkan kesejahteraan bagi orangorang yang ada di dalamnya. ${ }^{2}$

Namun setelah 18 tahun berdiri keberadaan KPPU terus menjadi sorotan publik terutama kewenangan KPPU yang belum maksimal. Sebagai lembaga pengawas, KPPU memiliki kewenangan melakukan penyelidikan, penuntutan dan memutus $^{3}$. Ketiga kewenangan tersebut baik secara normatif dan pada pelaksanaan dirasakan belum maksimal dimiliki KPPU sebagai lembaga yang diberi amanat untuk melakukan pengawasan sehingga mempersulit pelaksanaan fungsi dan tugas KPPU. Di bidang penyelidikan KPPU tidak memiliki kewenangan untuk melakukan penyitaan, penggeledahan sebagaimana lembaga yang memiliki kewenangan penyelidikan. Di bidang penuntutan KPPU tidak memiliki kewenangan untuk melakukan penyitaan terhadap suratsurat yang dibutuhkan dalam menuntut

${ }^{1}$ Arie Siswanto, Hukum Persaingan Usaha, Ceatakan ke-2, Bogor, Ghalia Indonesia, 2004, hlm. 93-94.

2 Ahmad Zuhairi, Konstruksi Perlindungan Konsumen Bagi Pengadu/Pelapor Kerugian Konsumen Dari Tuntutan Pencemaran Nama Baik Oleh Pelaku Usaha/ Produsen, Jurnal Ius Kajian Hukum dan Keadian, Magister Ilmu Hukum Universitas Mataram, Vol. III, Nomor 7, April 2015, hlm. 56.

Muh.Risnain, "Kedudukan Lembaga Quasi Peradilan dalam Sistem Peradilan Indonesia : Komisi Pengawas Persaingan Usaha" Vol.2 
perkara, kewenangan memutus perkara KPPU tidak memiliki kewenangan untuk mengeksekusi putusan KPPU sendiri.

Sementara di sisi lain Indonesian Competition Lawyers Association (ICLA) dan LKPU (Lembaga Kajian Persaingan dan Kebijakan Usaha) Fakultas Hukum Universitas Indonesia menilai kewenangan KPPU sebagai lembaga pemutus bertentangan dengan sistem peradilan di Indonesia yang menempatkan lembaga pengadilan sebagai satu-satunya lembaga yang memiliki kewenangan memutus. Bahkan secara ekstrem mereka menghendaki agar KPPU ditempatkan sebagai lembaga adminsitratif saja. Jika demikian legitimasi KPPU sebagai pengawas persaingan usaha di Indonesia kemudian dipertanyakan ${ }^{4}$.

Pada saat ini DPR dan Presiden telah memasukkan perubahan terhadap undangundnag antimonopoli dalam program legislasi nasional (prolegnas) 2-15-2019, sejak 2016 yang lalu telah dirancang dan dibahas oleh Badan Legislasi DPR RI, namun hingga kini belum ditetapkan menjadi undang-undang karena banyak isu yang kontrovesi di dalamnya termasuk di dalamnya isu penguatan kewenangan KPPU.

Dua pandangan yang kontras ini tentu tidak menguntungkan bagi pembangunan ekonomi nasional sehat dan adil sebagaimana diamanatkan Pasal 33 UUD NRI 1945. Oleh karena itu perlu dilakukan sebuah kajian yang mendalam terkait urgensi memperkuat kewenangan KPPU dalam mengawal dan mengawasi persaingan usaha yang akan memberikan kontribusi bagi pembangunan ekonomi nasional ke depan.

Artikel ini berusaha mengungkapkan keberadaan KPPU sebagai lembaga quasiyudisial yang memiliki peranan penting dalam membangun perekonomian

${ }^{4}$ http://www.hukumonline.com/berita/baca/ 1t59f 162 e 194852 /revisi-uu-persaingan-usaha-dinilai-akan-mematikan-pebisnis nasional, artikel ini juga akan membandingkan keberadaan KPPU dengan lembaga serupa yang dimiliki negara lain yang telah terlebih dahulu memiliki lembaga pengawas persaingan usaha, dan menemukan sebuah konsep penguatan kewenangan KPPU dalam mengawasi persaingan usaha di Indonesia.

Dari uraian latar belakang di atas memperlihatkan bahwa ada masalah yang belum terpecahkan terkait dengan belum maksimalnya kewenangan KPPU sebagai lembaga pengawas persaingan usaha nasional yang akan mempengaruhi pembangunan ekonomi nasional. Artikel ini kemudian mengidentifikasi beberapa masalah yang akan diuraikan dalam tulisan ini, pertama, bagaimana keterhubungan keberadaan KPPU dalam membangun perekonomian nasional yang sehat adil ? kedua, bagaimana konsep penguatan kewenangan KPPU dalam mengawasi persaingan usaha di Indonesia untuk membangun perekonomian nasional?.

Sedangkan metode penelitian ini adalah jenis penelitian yuridis-normatif. Penelitian ini mendiskripsikan dan menganalisis kebijakan hukum yang diambil pemerintah terkait kelembagaan KPPU sebagai pengawas persaingan usaha dan berusaha menemukan konsep penguatan KPPU sebagai lembaga quasi yudisialdalammewujdukan perekonomian nasional yang sehat dan adil. Sejalan dengan jenis penelitian yuridis normatif ,pendekatan pendekatan peraturan perundang-undangan dan pendekatan konseptual merupakan pendekatan yang tepat digunakan dalam penelitian ini. Pendekatan peraturan perundangundangan (statute approach) dilakukan dengan mengkaji berbagai peraturan perundang-undangan yang berkaitan dengan pemberantasan KPPU Pendekatan konseptual dilakukan dengan mengkaji dan menyusun konsep pengkuatan KPPU. Data yang dibutuhkan dalam penelitian ini adalah bahan hukum primer, sekunder 
dan tersier.Bahan-bahan hukum tersebut diperoleh melalui studi kepustakaan (library research). Metode analisis yang digunakan untuk membedah masalah dalam penelitian dan menemukan konsep adalah dengan menggunakan analisis yuridis kualitatif. Pada analisis demikian bahan hukum tidak dianalisis dengan menggunakan rumus dan metode statistik yang menggunakan metode kuantitatif, tetapi menggunakan metode analisis hukum melalui pendekatan penafsiran hukum dan konstruksi hukum dengan cara berpikir deduktif ${ }^{5}$.

\section{PEMBAHASAN}

\section{Hukum Persaingan Usaha dan Pem- bangunan Ekonomi Nasional}

Kehadiran hukum persaingan usaha di Indonesia harus dilihat dalam bingkai pembangunan ekonomi nasional yang didasarkan pada konstitusi sebagai landasan konstitusional pembangunan ekonomi nasional. Konstitusilah yang memberikan "nafas" dan rambu-rambu pembangunan ekonomi nasional. Pasal 33 Undang-undang Dasar Negara Republik Indonesia (UUD NRI) 1945 yang berfungsi sebagai landasan hukum tertulis dalam pembangunan ekonomi nasional $^{6}$. Norma yang terkandung dalam Pasal 33 UUD NRI 1945 tersirat bahwa pembangunan ekonomi nasional yang hendak dicapai haruslah berdasarkan pada prinsip demokrasi ekonomi yang bersifat kerakyatan yaitu terciptanya keadilan sosial bagi seluruh rakyat Indonesia. ${ }^{7}$

Di samping itu Pasal 33 UUD NRI 1945 tersebut memberikan petunjuk bahwa roda perekonomian nasional tidak dibiarkan begitu saja kepada pasar tetapi harus ada intervensi pemerintah

\footnotetext{
${ }^{5}$ Soetandyo Wignjosoebroto, Hukum : Konsep dan Metode, Malang : Setara Press, 2013, hlm. 52.

${ }^{6}$ Jilmy Assidiqie, Konstitusi Ekonomi Jakarta, Rajawali Press, 2011 hlm.45.

${ }^{7}$ Ayudha D. Prayoga, Dkk, Persaingan Usaha dan Hukum yang Mengaturnya di Indonesia, Partnership for Business Competition, Jakarta, 2001, hlm.117
}

yang mengatur aturan main (rule of the game) dalam menjalankan perekonomian nasional dalam bentuk peraturan perundang-undangan.

Menurut Sri Edi Swasono ${ }^{8}$ frase Perekonomian disusun... dalam kalimat Perekonomian disusun sebagai usaha bersama berdasarkan asas kekeluargaan yang terdapat dalam Pasal 33 ayat (1) UUD 1945 mengandung pengertian imperatif, artinya bahwa perekonomian nasional tidak dibiarkan berjalan sendiri atau mengikuti kekuatan-kekuatan yang ada atau kekuatan pasar bebas. Perkataan "disusun" mengisyaratkan adanya upaya membangun secara struktural perekonomian nasional melalui tindakan nyata. Tugas penyusunan bangunan ekonomi nasional tersebut merupakan kewajiban negara.

Keterlibatan pemerintah dalam mengatur ekonomi nasional dimaksudkan sebagai usaha untuk menghindari terjadinya suatu kondisi free fight liberalism, etatisme, persaingan usaha tidak sehat serta pemusatan kekuatan ekonomi pada satu kelompok dalam berbagai bentuk monopoli dan monopsoni yang merugikan masyarakat dan bertentangan dengan cita-cita keadilan sosial. ${ }^{9}$ Ketiga kondisi tersebut merupakan suatu kondisi ekstrim yang tidak dikehendaki oleh semangat perekonomian nasional yang demokratis yang melindungi eksistensi semua kelompok dalam aktifitas ekonomi. Kelompok yang cenderung terkena imbas kondisi di atas adalah kelompok usaha yang berada dalam posisi yang lemah.

Pasca bergulirnya reformasi bangunan ekonomi nasional diperkuat kembali dengan ketentuan yang terdapat dalam Pasal 33 ayat (4) UUD NRI 1945 yang

${ }^{8}$ Sri-Edi Swasono, Demokrasi Ekonomi: Keterkaitan usaha partisipatif Vs. Konsentrasi Ekonomi, Makalah dalam seminar "Pancasila sebagai Ideologi dalam Berbagai Bidang kehidupan Bermasyarakat, Berbangsa dan Bernegara", yang diselenggarakan B-7 Jakarta, 24 Oktober 1989, hlm.17

${ }^{9}$ Baca GBHN 1993-1998 
merupakan ketentuan tambahan terhadap Pasal 33 UUD 1945 yang berbunyi "Perekonomian nasional diselenggarakan atas demokrasi ekonomi dengan prinsip kebersamaan, efisiensi, berkeadilan, berkelanjutan, berwawasan lingkungan, kemandirian, serta dengan menjaga keseimbangan kemajuan dan kesatuan ekonomi nasional"10

Penegasanpencantumanprinsip-prinsip kebersamaan, efisiensi, berkeadilan, berkelanjutan, berwawasan lingkungan, kemandirian, serta dengan menjaga keseimbangan kemajuan dan kesatuan ekonomi pada ayat (4) di atas merupakan jalan tengah terhadap adanya tuntutan yang berkembang dalam masyarakat yang menghendaki asas kekeluargaan dalam Pasal 33 ayat (1) UUD 1945 dihapus dengan berdasarkan kenyataan bahwa kata "kekeluargaan" dimanfaatkan oleh kelompok tertentu untuk menguasai sumber ekonomi nasional. ${ }^{11}$

Ketentuan Pasal 33 UUD NRI 1945 merupakan landasan hukum untuk mengatur perekonomian nasional. Landasan itu pula yang menjadi landasan untuk mengatur hukum persaingan usaha di Indonesia. Untuk mewujudkan citacita yang tercantum dalam konstitusi tersebut maka diperlukan hukum yang berfungsi tidak hanya untuk menciptakan keamanan dan ketertiban masyarakat, tetapijuga hukum berfungsi sebagai sarana pembaharuan masyarakat. ${ }^{12}$ Di samping itu hukum juga merupakan sarana untuk mentransformasi masyarakat Indonesia yang merupakan bagian dari masyarakat dunia menuju era globalisasi.

\footnotetext{
10 Amandemen keempat Undang-Undang Dasar Negara Republik Indonesia 1945

${ }^{11}$ Jimly Asshidiqie, Konsolidasi Naskah UUD 1945 setelah Perubahan Keempat, Jakarta, Pusat studi Hukum Tata Negara Fakultas Hukum Universitas Indonesia, , 2002) hlm.57

12 Mochtar Kusumatmadja, Konsep-konsep Hukum dalam Pembangunan, Bandung Binacipta, ,1972, hlm.13 , lihat pula Otje Salman dan Eddy Damian (editor), Konsep-Konsep Hukum dalam Pembangunan: Kumpulan Karya Tulis Prof. Dr Mochtar Kusumaatadja, (Bandung, Alumni, ,2002) hlm.20
}

Kehadiran hukum dalam konteks pembangunan ekonomi diharapkan agar hukum dapat menciptakan kondisi stabilitas (stability), dapat memprediksi kondisi perekonomian di masa yang akan datang (predictability) dan menciptakan keadilan (fairness) dalam melakukan aktifitas ekonomi. ${ }^{13}$ Fungsi hukum sebagai stabilisator adalah bahwa hukum mampu menyeimbangkan dan mengakomodasi kepentingan-kepentingan yang saling bersaing dalam aktifitas ekonomi. Dalam konteks fungsi hukum yang predictability adalah bahwa hukum dapat memprediksi akibat dari suatu langkah-langkah yang diambil lebih khusus dalam hal ini adalah negara-negaraberkembang yang memasuki era globalisasi dan perdagangan bebas. Dalam konteks keadilan (fairness) bahwa hukum harus mampu menciptakan suatu perlakuan yang sama terhadap semua pelaku usaha dalam melakukan aktifitas ekonomi dan juga untuk menciptakan pola tingkah laku pemerintah untuk menjaga mekanisme pasar dan birokrasi yang berlebihan. ${ }^{14}$

Dalam konteks itu kehadiran hukum persaingan usaha merupakan elemen penting dalam sistem perekonomian nasional. Hukum persaingan dapat memberikan guidance sekaligus code of conduct dari perilaku pelaku usaha dan pemerintah dalam mengatur kegiatan ekonomi nasional. Hukum persaingan usaha sejatinya tidak melarang adanya persaingan usaha antara pelaku usaha karena bersaing merupakan merupakan suatu hal niscaya dalam kegiatan bisnis, tetapi mengatur perilaku usaha agar dalam menjalankan kegiatan usaha dilakukan dengan persaingan yang sehat dan jujur. Hukum persaingan usaha tidak melarang

13 Erman Rajagukguk, Hukum Ekonomi Indonesia : Memperkuat Persatuan Nasional, Mendorong Pertumbuhan Ekonomi dan Memperluas Kesejahteraan Sosial, makalah dalam seminar pembangunan Hukum nasional ke-VIII yang diadakan oleh BPHN Depkeh dan HAM, di Bali, Tahun 2003, hlm.7

${ }^{14}$ Ibid 
pelaku usaha menjadi sebuah perusahaan yang besar, tetapi hukum persaingan usaha mengatur bagaimana seorang pelaku usaha menjadi besar dengan cara yang fair dan ketika ia pelaku usaha menduduki posisi yang dominan dalam kegiatan usaha ia tidak kemudian menyalahgunakan posisi dominannya tersebut untuk mematikan pelaku usaha lain atau mencegah pelaku usaha untuk berusaha pada bidang yang sama.

Sebuah sistem perkonomian yang tidak didukung oleh hukum persaingan usaha maka kecenderungan terjadinya pasar yang terdistorsi dan persaingan tidak sehat merupakan sebuah kondisi yang tidak dapat terbantahkan. Kondisi demikian menimbulkan dampak negatif : pertama, matinya atau berkurangnya persaingan antar pelaku usaha; kedua, timbulnya praktek monopoli dimana pasar dikuasai hanya pelaku tertentu; ketiga, kecenderungan pelaku usaha mengeksploitasi konsumen dengan cara menjual mahal barang dan jasa tanpa dibarengi dengan kualitas yang memadai. ${ }^{15}$

Menyadari dampak negatif kondisi perekonomian yang monopoistik dan persaingan usaha tidak sehat di atas maka sebuah negara memerlukan hukum persaingan usaha. Menurut Khemani kehadiran hukum persaingan usaha untuk mengatur perekonomian di sebuah negara didasarkan pada pertimbangan ekonomi dan non-ekonomi. Pertimbangan ekonomi menghendaki kehadiran hukum persaingan usaha diharapkan untuk terciptanya efisiensi ekonomi sebuah negara. Tujuan non-ekonomis menghendaki tidak saja melahirkan efisiensi ekonomi sebuah negara tetapi terciptanya situasi politik ekonomi dan budaya ekonomi dan kestabilan ekonomi sebuah negara. Ketidakefisienan

${ }^{15}$ Hikmahanto Juwana, "Sekilas Hukum Persaingan Usaha dan UU No.5 tahun 1999", Jurnal Magister Hukum, 1999, hlm.32 perekonomian sebuah negara tidak hanya berdampak pada bangkrutnya perekonomian sebuah negara tetapi akan mempengaruhi situasi sosial, politik, pertahanan dan keamanan sebuah negara. Contoh yang paling dekat adalah kondisi perkonomian Indonesia yang terjadi pada tahun 1998 yang kolaps akibat krisis ekonomi yang menerpa Indonesia. Akibatnya bukan saja lemahnya mata uang rupiah terhadap mata uang asing dan bangkrut-nya perbankan nasional, tetapi krisis tersebut berdampak pada kondisi politik, pertahanan dan keamanan nasional Indonesia. Begitu dahsyatnya dampak krisis ekonomi tersebut sehingga mengkahiri kekuasaan politik rezim Soeharto yang telah berkuasa selama 32 tahun. Krisis ekonomi tersebut dipicu oleh situasi persaingan usaha yang tidak sehat. Perekonomian nasional dikuasai oleh sekelompok orang dengan memiliki hak ekonomi dan berbagai privilege yang diberikan oleh rezim Soeharto. Namun tidak mudah untuk menyatukan dua tujuan hukum persaingan usaha dalam satu bingkai sistem perekonomian nasional.

Menurut Khomeni sebagaimana yang dikutip Arie Siswanto ${ }^{16}$ tujuan hukum persaingan usaha adalah : Pertama, menjaga kondisi persaingan yang bebas. Menjaga kondisi persaingan usaha dalam kegiatan ekonomi dilandasi oleh alasan ekonomi berupa efisiensi maupun idiologi berupa adanya kebabasan berusaha bagi semua pelaku usaha. Kondisi persaingan usaha yang sehat akan berdampak pada alokasi dan realokasi sumber daya ekonomi yang efisien dan menumbuhkan inovasi bagi pelaku usaha dalam proses produksi maupun teknologi dalam menghasilkan barang dan jasa. Secara tidak langsung akan memberikan dampak positif bagi konsumen untuk menikmati barang dan jasa dengan kualitas tinggi dan harga murah. Kedua, mencegah penyalahgunaan

\footnotetext{
${ }^{16}$ Arie Siswanto, Op.cit, 2002, hlm.26-28
} 
Muh. Risnain | Konsep Penguatan Kewenangan Komisi Pengawas Persaingan Usaha Sebagai Lembaga......

kekuatan ekonomi (prevention abuse of economic power). Hukum persaingan usaha menghendaki agar sumber-sumber ekonomi tidak dikuasai oleh seorang atau sekelompok orang tertentu atau monoplistik. Kondisi perekonomian yang dikehendaki adalah kegiatan usaha yang proporsional dimana pihak yang memiliki kekuatan ekonomi yang kuat dan menduduki posisi monopolistik tidak merugikan pelaku usaha lain. Ketiga, melindungi konsumen (protection of consumers). Pihak yang paling terkena dampak dari kegiatan persaingan usaha adalah konsumen sebagai penikmatbarang dan jasa yang dihasilkan pelaku usaha. Jika kondisi persaingan usaha yang sehat maka konsumen akan diuntungkan, konsumen akan menikmati kualitas barang dan jasa yang tinggi dengan murah, sebaliknya jika kegiatan usaha terjadi dengan tidak adanya persaingan maka konsumen akan mendapatkan kualitas barang dan jasa yang rendah dengan harga yang mahal. Untuk itu hukum persaingan hadir untuk melindungi konsumen dari dampak buruk persaingan usaha tidak sehat dan monopolistik pelaku usaha.

Organisasi Perdagangan dan Pembangunan PBB (UNCTAD) menyatakan bahwa tujuan hukum persaingan usaha adalah : to control or eliminate restrictive agreements or arrangement among enterprises or acquisition and or abuse of dominant position of market power, which limit access to markets or otherwise unduly restrain competition, adversely affecting domestic or international trade or economic development.

Lebih khusus UCTAD mencantumkan tujuan hukum persaingan usaha adalah :

"the creation, encouragement, and protection competition, control of concentration of capital and/or economic power, encouragement of innovation; protection and promotion of social welfare and in par- ticular the interest of consumers, etc and take into account the impact of restrictive business practices on their trade and development"

Uraian tujuan hukum persaingan usaha yang dikemukakan UNCTAD di atas mengerucut pada beberapa tujuan; Pertama, hukum persaingan usaha bermaksud menghadirkan kondisi persaingan usaha yang sehat dalam ekonomi sebuah negara dengan melindungi persaingan itu sendiri, mengawasi pemusatan modal atau kekuatan ekonomi. Kedua, menciptakan inovasi bagi pelaku usaha. Ketiga, perlindungan dan promosi kesejahteraan sosial khususnya terhadap konsumen.

Seorang praktisi hukum persaingan usaha Rikrik Rizkiyana ${ }^{17}$ menyarikan beberapa pendapat pakar hukum persaingan usaha menyatakan bahwa tujuan hukum persaingan usaha adalah :

1) Melindungi pelaku usaha terutama pelaku usaha yang tidak dominan;

2) Melindungi konsumen dari ekonomi biaya tinggi dimana konsumen dihindari untuk mengeluarkan biaya yang tidak sesuai dengan kualitas barang yang dihasilkan konsumen

3) Melindungi negara dari inefisiensi kegiatan ekonomi yang dapat mengurangi kesejahteraan nasional;

4) Melindungi proses persaingan usaha itu sendiri.

Undang-Undang Nomor 5 tahun 1999 mencantumkan tujuan pembentukan hukum persaingan usaha di Indonesia adalah :

1) Menjaga kepentingan umum dan meningkatkan efisiensi ekonomi nasional sebagai salah satu upaya untuk meningkatkan kesejahteraan rakyat;

2) Mewujudkan iklim usaha yang kondusif melalui pengaturan persaingan usaha

${ }_{17}$ Rikrik Rizkiyana, Catatan Kritis Terhadap Hukum Acara Persaingan Usaha, makalah disampaikan dalam Lokakarya Penelitian Hukum Persaingan Usaha, KHN,2011, hlm.3-4 
yang sehat sehingga menjamin adanya kepastian kesempatan berusaha yang sama bagi pelaku usaha besar, pelaku usahamenengah, dan pelakuusahakecil;

3) Mencegah praktek monopoli dan atau persaingan usaha tidak sehat yang ditimbulkan oleh pelaku usaha; dan

4) Terciptanya efektivitas dan efisiensi dalam kegiatan usaha.

Tujuan yang diemban Undang-Undang Nomor 5 tahun 1999 di atas sebenarnya jika dibandingkan dengan tujuan hukum persaingan usaha yang disampaikan Khomeni dan UNCTAD di atas relatif memiliki kesamaan. Menjaga situasi persaingan yang sehat dalam sistem ekonomi nasional, menjaga kepentingan konsumen, dan melindungi pelaku usaha yang lain dari praktek persaingan curang merupakantujuanutamalahirnyaUndangUndang Persaingan Usaha. Namun terasa sulit jika semua tujuan yang diemban Undang-Undang Nomor 5 tahun 1999 tersebut dapat diwujudkan dalam sebuah kebijakan pemerintah maupun putusan KPPU terkait dengan kasus persaingan usaha. Memilih ketiganya merupakan sebuah hal yang terasa sulit dan dilematis. Di negara lain seperti amerika tujuan lahirnya undang-undang persaingan usaha lebih mengkerucut pada perlindungan konsumen dari perilaku curang dan monopolistik pelaku usaha. Ketika situasi persaingan dalam sebuah negara memiliki persaingan yang sempurna maka situasi ikutan seperti adanya kesempatan bagi pelaku usaha untuk ikut dalam aktifitas ekonomi dan perlindungan hak-hak konsumen merupakan dampak ikutan yang niscaya akan lahir.

Terhadap tujuan pembentukan Undang-Undang Nomor 5 tahun 1999 Rikrik Rizkiyana menyatakan bahwa beberapa hal yang perlu dikritisi dari tujuan undang-undang.

1) Undang-Undang No. 5 Tahun 1999 tidak menyatakan secara jelas bahwa undangundang ini ditujukan mencegah dan melarang setiap dan seluruh tindakan anti persaingan secara komprehensif karena tidak secara jelas bahwa tujuan ini adalah untuk menghindari adanya praktek perjanjian yang membatasi persaingan (restrictivebusinesspractices) " untuk menyalahgunakan posisi dominan (abuse of dominan posisition);

2) Tidak memberikan way out berapa prioritas atau keberpihakan kepada salah satu stakeholders (pelaku usaha, konsumen, atau negara) bila terjadi konflik antar kepentingan;

Beberapa tujuan yang tercantum sangat interpretatif dengan kata lain dapat memberikan peluang kepada pengambil kebijakan untuk menginterpretasikan secara subyektif seperti klausula "kepentingan umum" dan "melalui pengaturan persaingan usaha yang sehat".

\section{Peranan KPPU dalam Membangun Perekonomian Nasional yang sehat adil.}

Kehadiran Undang-Undang Nomor 5 Tahun 1999 tidak saja membawa angin baru bagi regulasi persaingan usaha di Indonesia yang selama ini diatur dalam berbagai peraturan perundang-undangan, namun juga melahirkan lembaga baru yaitu Komisi Pengawas Persaingan Usaha (KPPU). Dapat dikatakan bahwa kelahiran KPPU merupakan "anak kandung" yang dilahirkan reformasi hukum ekonomi di Indonesia. Di samping itu kehadiran KPPU kemudian menempatkan KPPU sebagai lembaga yang yang mengawal reformasi ekonomi dan kegiatan usaha di Indonesia.

Untuk menjalankan fungsi pengawasan undang-undang ini memberikan tugas kepada KPPU, yaitu :

a) melakukan penilaian terhadap perjanjian yang dapat mengakibatkan terjadinya praktek monopoli dan atau persaingan usaha tidak sehat sebagaimana diatur dalam Pasal4sampai dengan Pasal 16; 
b) melakukan penilaian terhadap kegiatan usaha dan atau tindakan pelaku usaha yang dapat mengakibatkan terjadinya praktek monopoli dan atau persaingan usaha tidak sehat sebagaimana diatur dalam Pasal 17 sampai dengan Pasal 24;

c) melakukan penilaian terhadap ada atau tidak adanya penyalahgunaan posisi dominan yang dapat mengakibatkan terjadinya praktek monopoli dan atau persaingan usaha tidak sehat sebagaimana diatur dalam Pasal 25 sampai dengan Pasal 28;

d) mengambil tindakan sesuai dengan wewenang Komisi sebagaimana diatur dalam Pasal 36;

e) memberikan saran dan pertimbangan terhadap kebijakan Pemerintah yang berkaitan dengan praktek monopoli dan atau persaingan usaha tidak sehat;

f) menyusun pedoman dan atau publikasi yang berkaitan dengan Undang-undang ini;

g) memberikan laporan secara berkala atas hasil kerja Komisi kepada Presiden dan Dewan Perwakilan Rakyat.

Untuk menjalankan tugas-tugas di atas, Pasal 36 UU No. 5 tahun 1999 memberikan kewenangan kepada KPPU untuk:

a) menerima laporan dari masyarakat dan atau dari pelaku usaha tentang dugaan terjadinya praktek monopoli dan atau persaingan usaha tidak sehat;

b) melakukan penelitian tentang dugaan adanyakegiatanusahadanatautindakan pelaku usaha yang dapat mengakibatkan terjadinya praktek monopoli dan atau persaingan usaha tidak sehat;

c) melakukan penyelidikan dan atau pemeriksaan terhadap kasus dugaan praktek monopoli dan atau persaingan usaha tidak sehat yang dilaporkan oleh masyarakat atau oleh pelaku usaha atau yangditemukanolehKomisisebagaihasil penelitiannya;

d) menyimpulkan hasil penyelidikan dan atau pemeriksaan tentang ada atau tidak adanya praktek monopoli dan atau persaingan usaha tidak sehat;

e) memanggil pelaku usaha yang diduga telah melakukan pelanggaran terhadap ketentuan undang-undang ini;

f) memanggil dan menghadirkan saksi, saksiahli, dansetiaporangyangdianggap mengetahui pelanggaran terhadap ketentuan undang-undang ini;

g) meminta bantuan penyidik untuk menghadirkan pelaku usaha, saksi, saksiahli, atau setiap orang sebagaimana dimaksud huruf e dan huruf f, yang tidak bersedia memenuhi panggilan Komisi;

h) meminta keterangan dari instansi Pemerintah dalam kaitannya dengan penyelidikan dan atau pemeriksaan terhadap pelaku usaha yang melanggar ketentuan undang-undang ini;

i) mendapatkan, meneliti, dan atau menilai surat, dokumen, atau alat buktilain guna penyelidikan dan atau pemeriksaan;

j) memutuskan dan menetapkan ada atau tidak adanya kerugian di pihak pelaku usaha lain atau masyarakat;

k) memberitahukan putusan Komisi kepada pelaku usaha yang diduga melakukan praktek monopoli dan atau persaingan usaha tidak sehat;

1) menjatuhkan sanksiberupatindakan administratif kepada pelaku usaha yang melanggar ketentuan Undangundang ini.

Ketentuan di atas sesungguhnya membagi kewenangan KPPU dalam 3 kategori. Pertama, kewengan penyelidikan. Pasal 36 huruf (a),(b),(c) dan (d) memberikan kewenangan KPPU untuk : 1). menerima laporan dari masyarakat dan atau dari pelaku usaha tentang dugaan terjadinya praktek monopoli dan atau persaingan usaha tidak sehat, 2). melakukan penelitian tentang dugaan adanya kegiatan usaha dan atau tindakan pelaku usaha yang dapat mengakibatkan terjadinya praktek monopoli dan 
atau persaingan usaha tidak sehat, 3). melakukan penyelidikan dan atau pemeriksaan terhadap kasus dugaan praktek monopoli dan atau persaingan usaha tidak sehat yang dilaporkan oleh masyarakat atau oleh pelaku usaha atau yang ditemukan oleh Komisi sebagai hasil penelitiannya, 4). menyimpulkan hasil penyelidikan dan atau pemeriksaan tentang ada atau tidak adanya praktek monopoli dan atau persaingan usaha tidak sehat.

Kedua, kewenangan menuntuntut pelaku usaha. Pasal $36 \operatorname{huruf}(\mathrm{e}),(\mathrm{f}),(\mathrm{g}),(\mathrm{h}),(\mathrm{i})$, : (e) memanggil pelaku usaha yang diduga telah melakukan pelanggaran terhadap ketentuan undang-undang ini, (f) memanggildan menghadirkan saksi, saksiahli, dansetiaporangyang dianggap mengetahui pelanggaran terhadap ketentuan undang-undang ini; (g) meminta bantuan penyidik untuk menghadirkan pelaku usaha, saksi, saksi ahli, atau setiap orang sebagaimana dimaksud huruf e dan huruf $\mathrm{f}$, yang tidak bersedia memenuhi panggilan Komisi, (h). meminta keterangan dari instansi Pemerintah dalam kaitannya dengan penyelidikan dan atau pemeriksaan terhadap pelaku usaha yang melanggar ketentuan undangundang ini, (i) mendapatkan, meneliti, dan atau menilai surat, dokumen, atau alat bukti lain guna penyelidikan dan atau pemeriksaan.

Ketiga, kewenangan judisial. Kewenangan untuk menjatuhkan sanksi kepada pelaku usaha. Kewenangan KPPU tersebut merupakan kewenangan yang super dan istimewa diberikan undangundang kepada KPPU karena KPPU diberikan kewenangan untuk menjatuhkansanksiberupatindakan administratif kepada pelaku usaha yang melanggar ketentuan UndangUndang Persaingan Usaha ${ }^{18}$.

Hal yang menarik adalah kewenangan KPPU untuk memutus dan menjatuhkan sanksi kepada pelakuusaha.Kewenanganmengadili dan menjatuhkan sanksi kepada KPPU merupakan yang dimiliki yang secara khusus diberikan kepada KPPU yang tidak dimiliki oleh lembaga independen lain. Hal ini menimbulkan pertanyaan apakah KPPU merupakan lembaga peradilanataulembagaadministratif. Terkait status kelembagaan KPPU dalam sistem peradilan di Indonesia menarik untuk dikutip pendapat Jimly Assidiqie ${ }^{19}$

“....jelas bahwa pada hakikatnya KPPU adalah lembaga peradilan dalam arti yang luas, atau setidaknya dapat disebut sebagai lembaga semi-peradilan. Sebagai lembaga peradilan yang bersifatadministratif, fungsi KPPU dapat digolongkan ke dalam lingkungan peradilan tata usaha negara, tetapi apabila dilihat dari bidang sengketa hak yang diselesaikannya, komisi ini dapat juga dikategorikan berada dalam lingkungan peradilan umum".

Pasal 30 ayat (2) UU No.5 tahun 1999 menentukan status kelembagaan KPPU sebagai lembaga independen yang terlepas dari pengaruh dankekuasaanPemerintah serta pihak lain. Berdasarkan Pasal 31 ayat (2) UU No.5 Tahun 1999 mekanisme pengisian jabatan komisioner KPPU dilakukan melalui mekanisme pengangkatan oleh Presiden atas persetujuan Dewan Perwakilan Rakyat. Mekanisme demikian memungkinkan

${ }^{18}$ Ridwan, Tiga Dimensi Hukum Administrasi Negara dan Peradilan Administrasi Negara, FH UII Press, Yogyakarta, 2009, hlm.146.

${ }_{19}$ Jimly assidiqie,Fungsi Campuran KPPU sebagai lembaga quasi-peradilan, jimly.com 
Muh. Risnain| Konsep Penguatan Kewenangan Komisi Pengawas Persaingan Usaha Sebagai Lembaga......

terjadinya check and balances ${ }^{20}$ antara pemerintah dan DPR dalam mengangkat komisioner KPPU.

Pasal30 ayat (3) Undang-Undang Nomor 5 tahun 1999 menentukan bahwa KPPU bertanggung jawab kepada Presiden. Penunjukan Presiden sebagai lembaga tempat KPPU bertanggung jawab tidak berarti bahwa KPPU merupakan lembagapemerintahatausubordinasi Presiden. Secara institusional KPPU tetap menjadi lembaga independen dan imparsial dalam menjalankan tugas dan wewenanganya. Pertanggungjawaban kepada Presiden dimaksudkan untuk tertib administratif semata karena KPPU menggunakan APBN dan menjalankan fungsi-fungsi pemerintahan $^{21}$

\section{KPPU Dalam Penegakan Hukum Per- saingan Usaha : Pengalaman Negara Lain}

Untuk melihat kedudukan KPPU dalam sistem peradilan di Indonesia peneliti melakukan studi perbandingan dengan lembaga-lembaga penegak hukum persaingan usaha di beberapa negara yang telah lebih dahulu memiliki lembaga serupa. Kajian perbandingan ini dimaksudkan untuk mencari acuan untuk meletakkan posisi lembaga penegak hukum persaingan usaha dalam sistem ketatanegaraan dan sistem peradilan. Peneliti mengambil beberapa negara sebagai bahan perbandingan yaitu:Jepang, Jerman, Amerika serikat dan Thailand.

\section{Lembaga Penegak Hukum Persaingan Usaha di Jepang}

Pengaturan hukum persaingan usaha di Jepang diatur dalam Antimonopoly law (AML),1947. Pasal 27 ayat (1)

\footnotetext{
${ }^{20}$ Jimly Assidiqie,Konstitusi dan Konstitusinalisme, Konstitusi Press, 2005, hml.112

${ }^{21}$ Bagir manan, Hukum Positif Indonesia : Suatu Kajian Teoritik,FH UII Press, Yogyakarta, 2004, hlm.50.
}

AML mengatur bahwa lembaga penegak persaingan usaha di jepang adalah Japan Fair Trade Commission (JFTC). JFTC merupakan lembaga Administratif yang bersifat independen. Secara administratif JFTC bertanggung jawab kepada Perdana Menteri. Pengisian jabatan komisioner JFTCdidasarkanpada penunjukanPerdana Menteri dengan persetujuan Parlemen. Pengangkatan dan pemberhentian komisioner JFTC dikonfirmasi kepada Kaisar Jepang. Persyaratan menjadi komisioner JFTC adalah memiliki keahlian di bidang hukum dan ekonomi. Walaupun diangkat oleh Perdana Menteri dan atas persetujuan Parlemen tidak menghilangkan independensi JFTC. IndependensiJFTC menyebabkan lembaga ini dibuktikan dalam setiap pengambilan keputusan yang tidak dapat dipengaruhi oleh lembaga negara lain termasuk Perdana Menteri dan Parlemen.

Sebagai lembaga penegak hukum persaingan usaha AML memberikan kewenangan kepada JFTC meliputi kewenangan di bidang administratif, kewenanganan yang bersifat quasilegislative dan quasi-judikatif.

Di bidang administratif (administrative power) JFTC memiliki kewenangan untuk : Menerima dan meneliti laporan dari perusahaan-perusahaan tentang pelanggaran terhadap AML, melakukan survey umum terkait aktivitas usaha, kondisi ekonomi dan kondisi monopolistik, melakukan fungsi konsultatif dengan perusahaan-perusahaan dan asosiasiasosiasi pelaku usaha, membicarakan masalah-masalah persaingan usaha dengan organisasi internasional dan otoritas hukum persaingan usaha.

Di bidang quasi-legislatif (quasijudicative power) JFTC memiliki kewenangan untuk :membuat peraturan tentang tindakan-tindakan pelaku usaha yang dianggap sebagai unfair competition, peraturan tentang penetapan harga jual dan harga beli comoditi tertentu, hukum 
acara di depan JFTC. Di bidang quasiyudikatif (quasi-judicative power) JFTC memiliki kewenangan untuk memeriksa dan mengadili kasus-kasus pelanggaran AML.

\section{Lembaga Penegak Hukum Persaingan Usaha Jerman}

Pengaturan persaingan usaha di Jerman diatur dalam Undang-Undang Perlindungan Persaingan Usaha (Gesetz gegen Wettbewerbs beschrankungen-GWB) Tahun 1957. Undang-undang tersebut mengatur secara komprehensif aspek persaingan usaha. Undang-undang ini mengatur tentang pembentukan lembaga penagawas persaingan usaha yaitu Federal Cartel Office (FCO) atau Bundeskartellamt.

Federal Cartel Office secara administratif bertanggung jawab kepada Menteri Perekonomian Federal. Dalam melaksanakan tugas dan kewenanngannya FCO bersifat independen. FCO berada di setiap negara bagian. FCO memiliki tugas melakukan investigasi dan mengumpulkan data-data dari perusahaan yang diduga melakukan kegiatan bisnis curang.

Dari sisi kelembagaan FCO memiliki kelembagaan dan kewenangan yang hampir sama dengan lembaga peradilan yang memiliki kewenangan untuk menjatuhkan putusan. Terhadap putusan FCO pihak yang tidak setuju dapat melakukan banding ke pengadilan.

Dalam penegakan hukum persaingan usaha, Jerman Memiliki organ lain yaitu monopolkommission (Monopolies Commission). Kewenangan yang dimiliki monopolkommission adalah kewenangan untuk pelaporan, review dan rekomendasi tidak memiliki kewenangan untuk memutus. ${ }^{22}$ Komisioner monopolkommission terdiri dari ahli hukum dan ahli ekonomi.

\section{Lembaga Penegak Hukum Persaingan Usaha Amerika}

${ }^{22}$ Arie Siswanto, Hukum Persaingan Usaha, Ghalia Indonesia, Jakarta, 2002, hlm.52

230 IUS Kajian Hukum dan Keadilan
Regulasi hukum persaingan usaha di AS mengalami perkembangan pengaturan sesuai perkembangan bisnis dan ekonomi AS. Undang-undang pertama yang mengatur persaingan usaha adalah Sherman Antitrust Act (1914), kemudian disusul oleh beberapa undang-undang yaitu Clayton Act (1914), Federal Trade Commission Act (1914), Robinson-Patman Act (1934), Celler-kefauver Anti Merger Act (1976), dan International Antitrust Enforcement Act (1994).

Kelembagaan Penegakan hukum persaingan usaha di AS diemban oleh dua lembaga yaitu Antitrust Division of The Department Of Justice (DOJ-AD) dan Federal Trade Commission (FTC). DOJ-AD merupakan lembaga yang berada di bawah Departemen of Justice yang merupakan bagian dari eksekutif yang dibentuk melalui Sherman Act. FTC dibentuk melalui Federal Trade Commission Act (1914). Kehadiran FTC dalam penegakan hukum persaingan usaha di AS untuk memperkuat penegakan hukum persaingan usaha.

Kedua lembaga penegakan hukum persaingan usaha di AS memiliki pembagian kewenangan yang berbebeda. DOJ-AD memiliki keweangan untuk menentukan apakah yang dilakukan pelaku usaha merupakan pelanggaran pidana atau pelanggaran perdata. Jika pelanggaran merupakan palanggaran pidana maka menjadi kewenangan DOJAD untuk mengajukan tuntutan melalui Pengadilan Federal (Federal District Court). Jika dalam penyelidikan tidak ditemukan pelanggaran pidana maka penyelidikan dilakukan oleh FTC. Jadi hubungan kerja antara DOJ-AD dan FTC terjadi manakala DOJ-AD tidak mengambil tindakan dalam menegakkan hukum persaingan usaha maka FTC dapat melakukan tindakan penegakan hukum.

FTC yang dibentuk melalaui FTC Act merupakan lembaga independen yang memiliki kewenangan yang luas. 
Muh. Risnain| Konsep Penguatan Kewenangan Komisi Pengawas Persaingan Usaha Sebagai Lembaga......

FTC memiliki kewenangan untuk mengeluarkan perintah penghentian kegiatan terhadap pelaku usaha yang diduga melanggar hukum persaingan usaha, mengawasi dan mengambil langkah-langkah hukum. FTC juga memiliki kewenangan untuk menegakkan hukum terhadap pelanggaran hukum persaingan usaha yang diatur Clyton Act, Robinson-Patman Act dan Celler-kevaufer antimerger Act. ${ }^{23}$

\section{Lembaga Penegak Hukum Persaingan Usaha Thailand}

Hukum persaingan usaha di Thailand diatur dalam Undang-Undang Persaingan Dagang (The Trade Competition Act) Tahun1999. Misi utama pengaturan persaingan usaha di negeri gajah putih adalah mengatur hubungan antara pelaku usaha di Thailand. Undang-undang persaingan dagang Thailand mengatur semua sektor usaha kecuali usaha-usaha yang dikecualikan dalam undang-undang. Dari sisi subastansi pengaturan persaingan dagang banyak mengadopsi normanorma hukum persaingan usaha yang ada dalam UU persaingan usaha AS dan Uni Eropa. Secara garis besar undang-undang persaingan dagang mengatur praktekpraktek perdagangan yang menciptakan monopoly dan mengurangi persaingan.

Undang-undang persaingan dagang Thailand membentuk lembaga penegak hukum persaingan usaha yaitu Komisi Persaingan Dagang (Trade Competition Commission/TCC). Secara kelembagaan TCC merupakan lembaga pemerintah yang berada di bawah Departemen perdagangan dalam negeri (Department of Internal Trade), sebuah departemen yang berada di bawah menteri perdagangan.

Keanggotaan TCC terdiri dari wakil dari berbagai berbagai macam lembaga-

${ }^{23}$ Johny Ibrahim, Hukum Persaingan Usaha : Filosofi, Teori Dan Implikasi Penerapanya Di Indonesia, cetakan kedua,Bayu Media, Malang,2007, hlm.143-145 lembaga pemerintah dan berasal dari 8 sampai 12 orang yang memiliki keahlian. Sebagian besar dari mereka dari pelaku usaha. TCC memiliki kewenangan antara lain:

1) membuat rekomendasi kepada menteri dalam hal membuat regulasi-regulasi dalam bidang persaingan usaha sebagaimana ditentukan dalam TCC.

2) menentukanpangsapasardan penjualan yang dapat menentukan posisi dominan dalam bisnis.

3) memberikan pertimbangan terkait dengan laporan pelanggaran undangundang persaingan dagang.

4) memberikan pertimbangan terkait dengan permohonan pengajuan merger yang dapat membatasi praktek dagang.

5) Menerima laporan dari pelaku usaha terkait tindakan dibidang hukum pidana yang melanggar larangan dalam undangundang persaingan perdagangan.

\section{Konsep Penguatan Kewenangan KPPU Menuju Perubahan Undang-Undang Antimopoli}

Pembahasan RUU antimonopoi yang sedang berlangsung antara DPR dan Presiden menurut ketua KPPU membahas lima isu kusial, penambahan denda jumlah terhadap pelaku usaha yang terbukti melanggar UU antimonopoli, kedua, pelibatan kepolisian dalam penggeledahan dan penyitaan, ketiga, keteribatan KPPU dalam proses pre merger, dan penguatan kewenangan KPPU agar lebih powerfull.

Isu penguatan kewenangan KPPU menjadi isu menarik dan kontroversial dalam proses pembahasan RUU ini. Pihak yang menghendaki KPPU lebih berkuasa maka hajatannya memperkuat kewenangan KPPU seperti yang ada sekarang ini. Kelompok kedua menghendaki kewenangan KPPU harus proporsional sesuai dengan sistem peradilan Indonesia. KPPU harus 
ditempatkan sebagai lembaga yang memiliki kekuasaan di bidang eksekutif. ${ }^{24}$

Menjawab isu kontroversial itu maka penulis memulai dari alasan mengapa diperlukan KPPU untuk mengawasi larangan praktik monopoli dan persaingan usaha tidak sehat. Sejalan dengan itu maka kehadiran KPPU sesungguhnya hendak menghadirkan keadilan sosial bagi seluruh rakyat Indonesia sebagaimana diamanatkan Pancasila. Kehadiran KPPU hendak meminimalisir terjadinya situasi perekonomian yang free fight liberalism ekonomi rimba dimana perekonomian nasional hanya dikuasai oleh segelintir orang. Namun di sisi lain tidak mematikan atau menghambat pertumbuhan pelaku usaha. KPPU kemudian harus berdiri pada dua kepentingan yang berbeda, kepentingan pelakuusaha dan kepentingan masyarakat sebagai konsumen.

Pada konteks filosofi demikian maka kehadiran KPPU sebagai pengawal dan pengawas keadilan sosial (the guardian of social justice) dalam membangun perekonomian adalah, pertama, menjaga kepentingan umum dan meningkatkan efisiensi ekonomi nasional sebagai salah satu upaya untuk meningkatkan kesejahteraan rakyat, kedua, mewujudkan iklim usaha yang kondusif melalui pengaturan persaingan usaha yang sehat sehingga menjamin adanya kepastian kesempatanberusahayangsamabagipelaku usaha besar, pelaku usaha menengah, dan pelaku usaha kecil; ketiga, mencegah praktek monopoli dan atau persaingan usaha tidak sehat yang ditimbulkan oleh pelaku usaha; dan terciptanya efektivitas dan efisiensi dalam kegiatan usaha. Pada konteks yang demikian dengan beban yang begitu besar maka KPPU memang harus memiliki kewenangan yang lebih luas dan proporsioal.

${ }^{24} \mathrm{http}: / /$ www.hukumonline.com/berita/baca/lt59238d3e414c6/chandra-m-hamzah--dudukkan-kembali-kppu-pada-posisi-yang-benar
Kewenangan KPPU untuk melakukan penyelidikan, penuntutan dan memutus perkara sebagaimana yang ada dalam undang-undang antimonopoli sekarang ini adalah kewenangan yang propoprsioanal dengan tujuan yang hendak diwujudkan oleh undang-undang antimonopoli. Maka menurut penulis kewenangan KPPU yang lemah sekarang ini seperti kewenangan untuk melakukan penggeledahan harus diperkuat dengan memberikan kewenangan kepada KPPU untuk melakukan penyitaan secara mandiri sebagaimana dimiliki oleh kepolisian. Oleh karena itu, KPPU harus memiliki penyidik sendiri. Pembentuk undang-undang dapat mencontohi kewenangan yang dimiliki penyidik KPK yang memiliki kewenangan penyitaan dan penggeledahan sendiri khusus di bidang persaingan usaha dan antimonopoly. Penyidiknya dapat diambil dari kepolisian khusunya pada direktorat tindak pidana ekonomi.

Kewenangan KPPU lain yang perlu diperkuat adalah kewenangan melaksanakan putusan. Salah satu hambatan yang dihadapi KPPU adalah ketidakmampuan untuk mengeksekusi putusan yang telah diputuskan oleh KPPU. Praktis putusan KPPU itu hanya mengharapkan kesadaran dari pelaku usaha yang telah dihukum. Oleh karena itu perlu penguatan kewenangan KPPU untuk memaksa pelaku usaha melalui instrument hukum yang dapat memaksa pelaku usaha yang tidak mau mentaati hukuman KPPU. Instrumen hukum yang ada sekarang dengan menjadikan sebagai perbuatan pidana (kriminalisasi) terhadap pelaku usaha yang tidak mau menjalankan putusan KPPU instrumen yang kurang efektif untuk dapat dilaksanakan.

\section{SIMPULAN}

Keberdaan KPPU dalam membangun perekonomian nasional yang sehat adil adalah perwujudan intervensi negara dalam mewujudkan negara kesejahteraan 
Muh. Risnain | Konsep Penguatan Kewenangan Komisi Pengawas Persaingan Usaha Sebagai Lembaga......

yaitu menghadirkan keadilan sosial bagi seluruh rakyat Indonesia. Dalam demokrasiekonomiKPPUberperan sebagai pengawas dan pengawal terwujudnya demokrasi ekonomi yang dapat memberi kontribusi positif bagi kepastian berusaha, perlindungan konsumen dan petumbuhan perekonomian secara adil. Penguatan kewenangan KPPU yang ada sekarang ini dilakukan dengan menambah kewenangan melakukan penyitaan dan penggeledahan secara mandiri oleh KPPU dan KPPU dapat secara efektif melaksanakan putusan yang dikeluarkan KPPU.

Untuk memperkuat kewenangan KPPU maka hendaknya perubahan UU antimonopoli yang sedang dibahas DPR dan presiden hingga kini untuk menambah kewenangan -kewenangan KPPU yang ada pada pasal 35 dan 36 UU antimonopoly dapat dilakukan perubahan dalam rangka memperkuat kewenangankewenangan KPPU. Melakukan kajian perbandingan dengan lembaga pengawas dan penegak hukum persaingan usaha di negara lain seperti di Amerika Serikat, Jerman dan Jepang hendaknya dilakukan DPR RI dan Presiden dalam rangka memperkuat Kewenangan KPPU.

\section{DAFTAR PUSTAKA}

\section{Buku}

Arie Siswanto, 2002. Hukum Persaingan Usaha, Ghalia Indonesia, Bogor.

Ayudha D. Prayoga, Dkk, 2001. Persaingan Usaha dan Hukum yang Mengaturnya di Indonesia, Partnership for Business Competition, Jakarta.

Erman Rajagukguk, 2003. Hukum Ekonomi Indonesia : Memperkuat Persatuan Nasional, Mendorong Pertumbuhan Ekonomi dan Memperluas Kesejahteraan Sosial, makalah dalam seminar pembangunan Hukum nasional ke-VIII yang diadakan oleh
BPHN Depkeh dan HAM, di Bali, Tahun.

Jimly Asshidiqie, 2002. Konsolidasi Naskah UUD 1945 setelah Perubahan Keempat, Pusat studi Hukum Tata Negara Fakultas Hukum Universitas Indonesia, Jakarta.

Mochtar Kusumatmadja, $\quad 1972$ Konsep-konsep Hukum dalam Pembangunan, Binacipta, Bandung.

Otje Salman dan Eddy Damian (editor), 2002. Konsep-Konsep Hukum dalam Pembangunan: Kumpulan Karya Tulis Prof. Dr Mochtar Kusumaatadja, Alumni, Bandung.

Rikrik Rizkiyana, 2011. Catatan Kritis Terhadap Hukum Acara Persaingan Usaha, makalah disampaikan dalam Lokakarya Penelitian Hukum Persaingan Usaha, KHN.

Sri-Edi Swasono, 1989. Demokrasi Ekonomi: Keterkaitan usaha partisipatif Vs. Konsentrasi Ekonomi, Makalah dalam seminar "Pancasila sebagai Ideologi dalam Berbagai Bidang kehidupan Bermasyarakat, Berbangsa dan Bernegara", yang diselenggarakan B-7 Jakarta, 24 Oktober.

Indonesia, Undang-Undang Nomor 5 Tahun 1999 tentang Larangan Praktek Monopoli dan Persaingan Usaha Tidak Sehat, Lembaran Negara Republik Indonesia Nomor 33

\section{Baca GBHN 1993-1998}

World Bank Report (unpublished) 1994

\section{Jurnal}

Hikmahanto Juwana, Sekilas Hukum Persaingan Usaha dan UU No.5 tahun 1999, Jurnal Magister 
Hukum, 1999.

Zuhairi, A. (2015). Konstruksi Perlindungan Hukum Bagi Pengadu/Pelapor Kerugian Konsumen Dari Tuntutan Pencemaran Nama Baik Oleh Pelaku Usaha/Produsen. Jurnal IUS Kajian Hukum dan Keadilan, $3(1)$. 